\title{
Efektivitas Penggunaan Blok Aljabar dalam Penyelesaian Persamaan Kuadrat Dengan Teknik Kuadrat Sempurna
}

\author{
Sukma Adi Perdana ${ }^{1 *}$, Febrian $^{2}$ \\ ${ }^{1,2}$ Universitas Maritim Raja Ali Haji, Kota Tanjungpinang, Provinsi Kepulauan Riau 29124, Indonesia \\ Pengiriman: 14 Desember 2018; Diterima: 23 April 2019; Publikasi: 30 April 2019 \\ DOI: https://doi.org/10.31629/jg.v4i1.852
}

\begin{abstract}
Abstrak
Penelitian ini bertujuan untuk melihat efektivitas penggunaan blok aljabar dalam rangka membantu siswa kelas IX menyelesaikan permasalahan persamaan kuadrat dengan teknik kuadrat sempurna. Blok aljabar digunakan dalam rangka membantu siswa dalam menghadapi kesulitan-kesulitan yang muncul dalam berpikir abstrak yang dibutuhkan ketika menyelesaikan persamaan kuadrat dengan teknik kuadrat sempurna. Ini penting untuk dikaji karena kesulitan dalam berpikir abstrak dalam menggunakan teknik kuadrat sempurna adalah salah satu hambatan yang dialami oleh siswa-siswa kelas IX dalam menyelesaikan masalah persamaan kuadrat. Hasil dari eksperimen memperlihatkan bahwa proses pembelajaran dengan menggunakan blok aljabar dalam menyelesaikan persamaan kuadrat dengan teknik kuadrat sempurna memberikan hasil yang lebih baik dari pembelajaran yang dilakukan dengan metode konvensional.
\end{abstract}

Kata Kunci: persamaan kuadrat; teknik kuadrat sempurna; blok aljabar; berpikir abstrak

\begin{abstract}
This study aims to look at the effectiveness of the use of algebra blocks in order to help grade IX students solve the problem of quadratic equations by using completing square technique. Algebra blocks are used in order to help students deal with difficulties that arise in abstract thinking needed when solving quadratic equations with completing square technique. This is important to study because the difficulty in abstract thinking in using the completing square technique is one of the obstacles experienced by grade IX students in solving the problem of quadratic equations. The results of the experiments show that the learning process by using algebraic blocks in solving quadratic equations by using completing square technique gives better results than learning delivered by conventional methods.
\end{abstract}

Keywords: quadratic equation; perfect quadratic technique; algebra blocks; abstract thinking

\section{Pendahuluan}

Solusi dari persamaan kuadrat adalah nilai-nilai yang apabila disubsitusikan ke persamaan kuadrat akan memberi nilai nol kepada persamaan tersebut. Solusi masalah persamaan kuadrat dapat didapat dengan tiga cara penyelesaian seperti faktorisasi, dengan menggunakan rumus $\mathrm{ABC}$, dan teknik kuadrat sempurna. De Lima \& Tall (2010) mengungkapkan bahwa guru mengajarkan ketiga teknik tersebut tapi lebih mengarahkan pada penggunaan rumus $\mathrm{ABC}$ dengan keyakinan bahwa hal tersebut akan membuat siswa dapat menyelesaikan segala bentuk persamaan kuadrat 


\section{JURNAL GANTANG. Maret 2019; IV(1): 71 - 77 \\ p-ISSN. 2503-0671 \\ e-ISSN. 2548-5547}

yang diberikan pada tes. Akibatnya sebagian besar siswa fokus pada penggunaan simbol pada rumus $\mathrm{ABC}$ dan sulit untuk memahami solusi dari persamaan kuadrat yang diberikan seperti bentuk $(x-2)(x-3)=0$. Jika ditelaah, hal ini dikarenakan tingkat pemahaman mengenai konsep aljabar di kalangan siswa masih tergolong rendah sehingga siswa mengalami kesulitan dalam menyelesaikan persamaan kuadrat (Fachrudin, 2015; Lian \& Yew, 2012; Radford \& Guérette, 2000).

Penyelesaian masalah persamaan kuadrat dengan teknik kuadrat sempurna bukanlah sebuah hal yang mudah untuk dikuasai. Kesulitan dalam memahami teknik persamaan kuadrat untuk menyelesaikan masalah persamaan kuadrat salah satunya dipengaruhi oleh ide-ide abstrak yang berkaitan dengan hal tersebut. Ide-ide abstrak yang muncul pada proses penyelesaian persamaan kuadrat dengan teknik kuadrat sempurna tidaklah mudah apabila pembelajaran dilakukan tanpa pemaknaan pada ide abstrak tersebut. Ini seperti yang dinyatakan oleh Foster (2007) yakni apabila pengajaran ide-ide abstrak pada sebuah topik matematika diajarkan tanpa kehadiran makna, maka pemahaman akan topik tersebut tidak akan didapat oleh siswa. Siswa semestinya mengalami sendiri atau mempunyai pengalaman terhadap sebuah konsep untuk memahami makna sebuah topik matematika.

Pembelajaran dengan pemaknaan dapat dilakukan dengan menghadirkan aspek geometri pada sebuah proses penyelesaian masalah matematika. Proses pembelajaran dengan menghadirkan aspek geometri diharapkan dapat membantu dalam memberi pemaknaan pada ideide abstrak yang muncul pada sebuah proses aljabar. Hal ini juga berlaku pada penyelesaian persamaan kuadrat dengan teknik kuadrat sempurna. Dalam penyelesaian persamaan kuadrat, kehadiran aspek geometri pada penyelesaian masalah matematika disebut dengan naive geometry.

Sejumlah penelitian dengan fokus naive geometry telah diterapkan (Kusumawati, 2017; Ulfa, 2017; Fachrudin, 2015; Fachrudin \& Putri, 2014). Hasil menunjukkan bahwa naive geometry dapat digunakan dalam memahami penyelesaian persamaan kuadrat. Hal ini dikarenakan naive geometry dapat digambarkan sebagai proses manipulasi bentuk geometri dari persamaan kuadrat sehingga penemuan akar persamaan kuadrat lebih terasa sensible dan dipahami bermakna oleh siswa. Walaupun demikian, sebuah perspektif yang menekankan pada proses peninjauan keefektifan penggunaan nä̈ve geometry dalam sebuah pembelajaran masih dirasa sangat diperlukan.

Dalam rangka mendudukkan perspektif tersebut dilakukan sebuah penelitian dengan desain pembelajaran nä̈ve geometry berbantuan media fisik blok aljabar. Desain pembelajaran pada penelitian menekankan metode penyelesaian persamaan kuadrat dengan teknik kuadrat sempurna dengan menggunakan blok aljabar sebagai alat bantu dalam memahami ide-ide abstrak yang muncul pada teknik kuadrat sempurna. Oleh karena itu penelitian ini mencoba mengeksplorasi bagaimana efektivitas aspek geometri melalui penggunaan blok aljabar dapat membantu siswa kelas IX menyelesaikan permasalahan persamaan kuadrat dengan teknik kuadrat sempurna dibandingkan dengan penggunaan metode penyelesaian yang konvensional yang tanpa melibatkan blok aljabar.

\section{Metode Penelitian}

Penelitian dilakukan di Sekolah Menengah Pertama (SMP) Negeri 17 Bintan, Kepulauan Riau. Dua kelompok siswa kelas IX dipilih secara acak dalam penelitian ini. Satu kelas dijadikan kelas kontrol dan kelas lainnya dijadikan kelas eskperimen. Untuk melihat dampak perlakuan terhadap hasil belajar matematika siswa digunakan rancangan penelitian The Static Group Comparison: Randomized Control Group Only Design. Hal ini sesuai dengan pendapat Suryabrata (2004) yang digambarkan sebagai berikut:

Tabel 1.

Rancangan Penelitian Randomized Control Group Only Design

\begin{tabular}{lccc} 
& Pretes & Treatment & Postes \\
\hline Eksperimen & - & $\mathrm{X}$ & $\mathrm{T}$ \\
\hline Kontrol & - & - & $\mathrm{T}$
\end{tabular}


Keterangan :

$X$ : Penggunaan Blok aljabar dalam menyelesaikan permasalahan persamaan kuadrat

$\mathrm{T}$ : Tes akhir yang diberikan pada kelas eksperimen dan kelas kontrol

Untuk menganalisis data hasil belajar siswa dilakukan uji $\mathrm{t}$, dengan terlebih dahulu melakukan uji normalitas dan uji homogenitas variansi terhadap data sampel. Apabila asumsi normalitas dan homogenitas variansi tidak terpenuhi maka analisis dilakukan dengan uji non parametrik Mann Whitney. Langkah-langkah teknik analisis data hasil belajar dilakukan melalui uji normalitas dan uji homogenitas variansi. Uji normalitas bertujuan untuk melihat apakah data sampel berdistribusi normal atau tidak. Uji yang digunakan adalah uji AndersonDarling dengan bantuan software MINITAB. Sedangkan uji homogenitas berguna untuk melihat apakah kedua sampel mempunyai varians yang homogen atau tidak. Untuk menguji homogenitas dilakukan uji F. Untuk melihat apakah data mempunyai variansi yang homogen atau tidak, digunakan interpretasi P-value. Data mempunyai variansi yang homogen jika $\mathrm{P}$-value yang diperoleh lebih besar dari taraf nyata yang telah ditetapkan dan sebaliknya (Syafriandi, 2001).

Untuk mengetahui apakah hasil belajar matematika kelompok eksperimen berbeda dari kelompok kontrol dilakukan uji t dua sampel yang independen atau uji Mann Whitney. Hipotesis yang diujikan:

$\mathrm{H}_{0}: \mu$ eksperimen $\leq \mu$ kontrol
$\mathrm{H}_{1}: \mu$ eksperimen $>\mu$ kontrol

Jika P-value yang diperoleh lebih kecil dari taraf nyata yang ditetapkan maka tolak $\mathrm{H}_{0}$ dan sebaliknya terima $\mathrm{H}_{0}$.

Terkait desain pembelajaran dijelaskan sebagai berikut. Tahapan pertama dalam pembelajaran dengan menggunakan blok aljabar dalam menyelesaikan persamaan kuadrat dengan teknik kuadrat sempurna adalah melakukan apersepsi tentang materi mengenai persamaan linear. Ini dilakukan untuk mengingatkan siswa akan konsep solusi dari permasalahan persamaan linear. Ditahap ini siswa didorong untuk mengingat tentang konsep persamaan linear dengan menyelesaikan beberapa latihan tentang menemukan solusi persamaan linear.

Tahapan kedua adalah mengajak siswa untuk membahas konsep persamaan kuadrat dan dengan mengaitkannya dengan konsep persamaan linear, lalu siswa digiring untuk menemukan apa yang dimaksud dengan solusi persamaan kuadrat. Setelah siswa mampu menunjukkan solusi dari persamaan kuadrat sederhana yang disajikan maka tahap pembelajaran dilanjutkan ke tahapan selanjutnya.

Pada tahapan ketiga yaitu mengajak siswa untuk memahami konsep kuadrat sempurna. Ini dilakukan agar siswa mampu memahami konsep kuadrat sempurna dan memanfaatkan konsep kuadrat sempurna sebagai salah satu teknik dalam menyelesaikan persamaan kuadrat. Pada tahapan ini juga dikenalkan blok aljabar dan mengajak siswa untuk membentuk sebuah persegi dengan blok aljabar sebagai representasi dari kuadrat sempurna. Sebagai contoh diberikan kuadrat sempurna sebagai berikut:

$$
(x+1)^{2}=(x+1)(x+1)
$$

Maka siswa membentuk sebuah persegi dengan blok aljabar sebagai bentuk interpretasi visual dari blok aljabar diatas sebagai berikut:

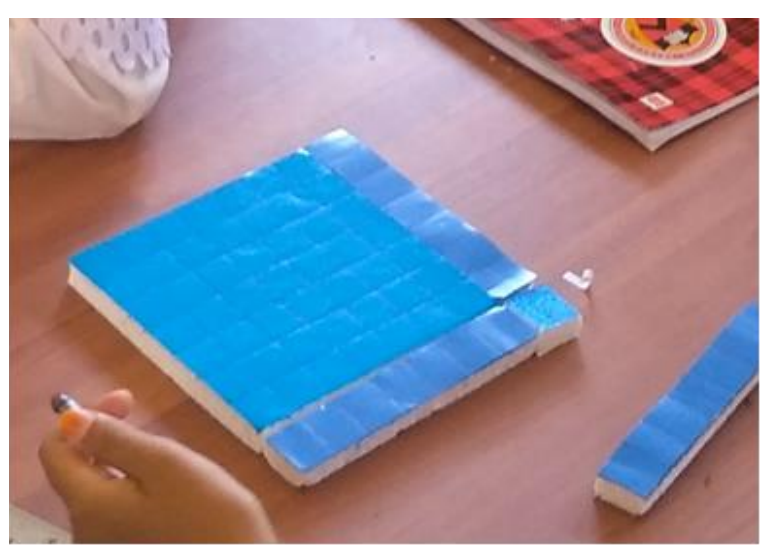

Gambar 1. Siswa membentuk sebuah persegi dengan blok aljabar

Tahapan selanjutnya adalah mengajak siswa menggunakan blok aljabar yang merupakan interpretasi visual dari kuadrat sempurna untuk menyelesaikan persamaan kuadrat dengan teknik 
JURNAL GANTANG. Maret 2019; IV(1): 71 - 77

p-ISSN. 2503-0671

e-ISSN. 2548-5547

kuadrat sempurna. Diharapkan dengan bantuan interpretasi blok aljabar dapat membantu siswa dalam menyusun bentuk kuadrat sempurna dalam penyelesaian persamaan kuadrat. Setelah mahasiswa mahir menggunakan blok aljabar maka tahap pembelajaran dilanjutkan ketahapan selanjutnya yaitu mengaplikasikan konsep blok aljabar kedalam prosedur penyelesaian persamaan kuadrat dengan teknik kuadrat sempurna tanpa menghadirkan alat peraga blok aljabar. Adapun aktvitas siswa seperti gambar berikut.

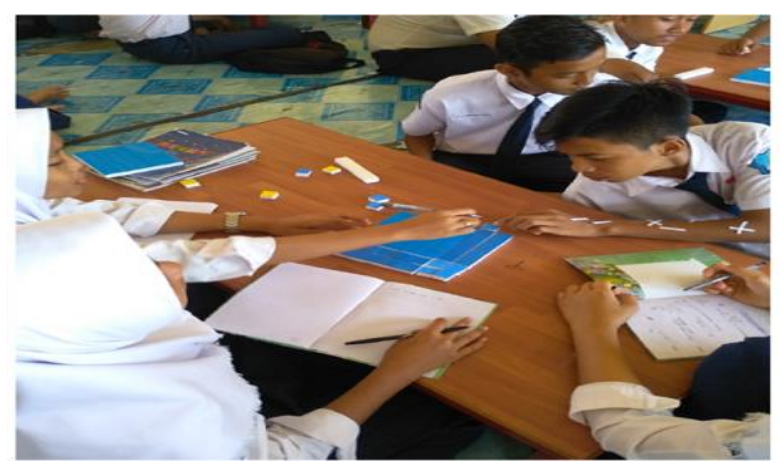

Gambar 2. Siswa sedang mengaplikasikan konsep blok aljabar

Tahapan kelima adalah mengaplikasikan konsep blok aljabar ke dalam prosedur penyelesaian persamaan kuadrat dengan teknik kuadrat sempurna tanpa menghadirkan alat peraga blok aljabar. Prosedur penyelesaian tersebut dijelaskan dalam langkah-langkah berikut.

$$
a^{2}+b x+c=0
$$

Ambil $\frac{b}{2}$

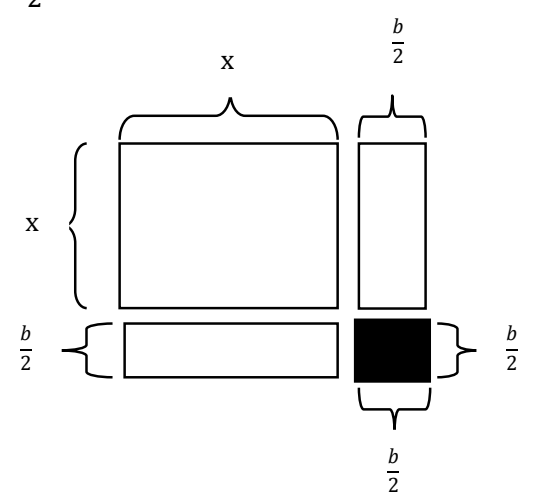

Gambar 3. Ilustrasi penambahan kuadrat sempurna

Lalu tambahkan nilai dari $\left(\frac{b}{2}\right)^{2}$ pada kedua ruas persamaan.

$$
\begin{gathered}
x^{2}+b x+c+\left(\frac{b}{2}\right)^{2}=0+\left(\frac{b}{2}\right)^{2} \\
\left(x^{2}+b x+\left(\frac{b}{2}\right)^{2}\right)+c=\left(\frac{b}{2}\right)^{2} \\
\left(x^{2}+b x+\left(\frac{b}{2}\right)^{2}\right)+c=\left(\frac{b}{2}\right)^{2} \\
\left(x^{2}+b x+\left(\frac{b}{2}\right)^{2}\right)=\left(\frac{b}{2}\right)^{2}-c \\
\left(x+\frac{b}{2}\right)^{2}=\left(\frac{b}{2}\right)^{2}-c \\
x+\frac{b}{2}= \pm \sqrt{\left(\frac{b}{2}\right)^{2}-c} \\
x=-\frac{b}{2} \pm \sqrt{\left(\frac{b}{2}\right)^{2}-c}
\end{gathered}
$$

Sehingga didapat

$$
\begin{aligned}
& x_{1}=-\frac{b}{2}+\sqrt{\left(\frac{b}{2}\right)^{2}-c} \\
& x_{2}=-\frac{b}{2}-\sqrt{\left(\frac{b}{2}\right)^{2}-c}
\end{aligned}
$$

Contoh kasus ketika ketika siswa diminta untuk menyelesaikan persamaan kuadrat $x^{2}-6 x+$ $8=0$ dengan teknik kuadrat sempurna.

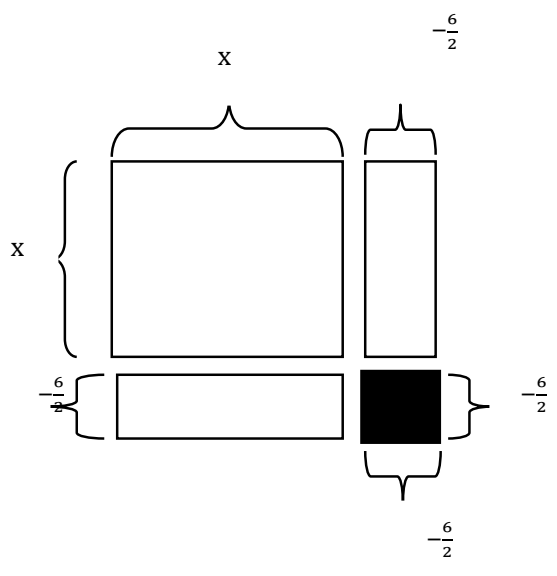

Gambar 4. Ilustrasi kuadrat sempurna pada soal

$$
x^{2}-6 x+8=0
$$

$$
x^{2}-6 x+8+\left(-\frac{6}{2}\right)^{2}=0+\left(-\frac{6}{2}\right)^{2}
$$




$$
\begin{gathered}
x^{2}-6 x+(-3)^{2}+8=(-3)^{2} \\
\left(x^{2}-6 x+(-3)^{2}\right)=(3)^{2}-8 \\
(x-3)^{2}=9-8 \\
(x-3)^{2}=1 \\
x-3=\sqrt{1} \\
x-3= \pm 1 \\
x_{1}=1+3=4 \\
x_{2}=-1+3=2
\end{gathered}
$$

\section{Hasil dan Pembahasan}

Statistika deskriptif dari data kelas eksperimen dan kelas kontrol dipaparkan sebagai berikut

Tabel 2.

Data kelas eksperimen dan kelas kontrol

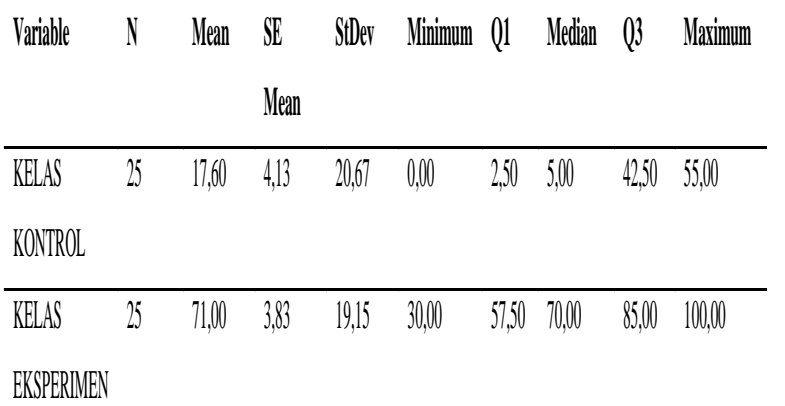

Sebelum dilakukan uji perbandingan dua sampel maka dilakukan uji prasyarat yakni uji homogenitas variansi dan uji normalitas untuk melihat uji perbandingan apa yang digunakan untuk proses perbandingan dua sampel dalam rangka menjawab hipotesis penelitian yang kita ajukan. Jika dari uji prasyarat yang telah dilakukan menunjukkan bahwa data memiliki variansi yang homogen dan kedua kelompok data berasal dari populasi yang berdistribusi normal maka digunakan uji perbandingan dua sampel parametrik yaitu uji $t$ untuk dua sampel independen.

Seandainya hasil uji prasayarat tidak memenuhi dua syarat kesamaan atau homogenitas variansi dan kenormalan data untuk dua kelompok data maka uji perbandingan dua sampel yang digunakan adalah uji perbandingan dua sampel nonparametrik yakni uji Mann-Whitney. Perhitungan uji prasayarat dan uji perbandingan dua sampel dilakukan dengan bantuan perangkat lunak pengolah data Minitab.

Hasil uji normalitas untuk kedua kelompok data menunjukkan bahwa untuk kelas eksperimen data berdistribusi normal dikarenakan $\mathrm{p}$ value sebesar 0.341 lebih besar dari alpha yang ditetapkan sebesar 0.05. Hasil dari uji normalitas kelas kontrol menunjukkan data tidak berdistribusi normal, ini ditunjukkan dengan $\mathrm{p}$ value yang dihasilkan sebesar 0.01 yang lebih kecil dari alpha yang ditetapkan sebesar 0.05.

Dikarenakan kelas kontrol tidak berdistribusi normal maka uji perbandingan dua sampel yang digunakan adalah uji non parametrik yakni uji Mann Whitney. Berikut hasil uji Mann Whitney yang dilakukan.

Tabel 3.

Tabel Uji Mann Whitney untuk perbandingan dua sampel

\begin{tabular}{l} 
Mann-Whitney Test and CI: KELAS EKSPERIMEN; KELAS KONTROL \\
N Median \\
KELAS EKSPERIMEN 2570,00 \\
KELAS KONTROL $25 \quad 5,00$ \\
Point estimate for $\eta 1$ - $\eta 2$ is 55,00 \\
95,2 Percent CI for $\eta 1$ - $\eta 2$ is (45,00;70,00) \\
W =928,5 \\
Test of $\eta 1=\eta 2$ vs $\eta 1>\eta 2$ is significant at 0,0000 \\
The test is significant at 0,0000 (adjusted for ties) \\
\hline
\end{tabular}

Hipotesis yang diujikan:

$\mathrm{H}_{0}: \mu$ eksperimen $\leq \mu$ kontrol

$\mathrm{H}_{1}: \mu$ eksperimen $>\mu$ kontrol

Jika p-value yang diperoleh lebih kecil dari taraf nyata atau alpha yang ditetapkan sebesar 0.05 maka tolak $\mathrm{H}_{0}$ dan sebaliknya terima $\mathrm{H}_{0}$.

Dari hasil perhitungan uji Mann Whitney memberikan nilai p-value sebesar 0.0000 yang artinya lebih kecil dari alpha yang ditetapkan sebesar 0.05. Sehingga yang dilakukan adalah tolak $\mathrm{H}_{0}$. Ini artinya $\mu$ eksperimen lebih besar dari hasil $\mu$ kontrol. Menunjukkan bahwa pencapaian kelas eksperimen lebih baik dari pada kelas kontrol. Untuk lebih jelasnya seperti digambarkan pada boxplot berikut. 


\section{JURNAL GANTANG. Maret 2019; IV(1): 71 - 77 \\ p-ISSN. 2503-0671 \\ e-ISSN. 2548-5547}

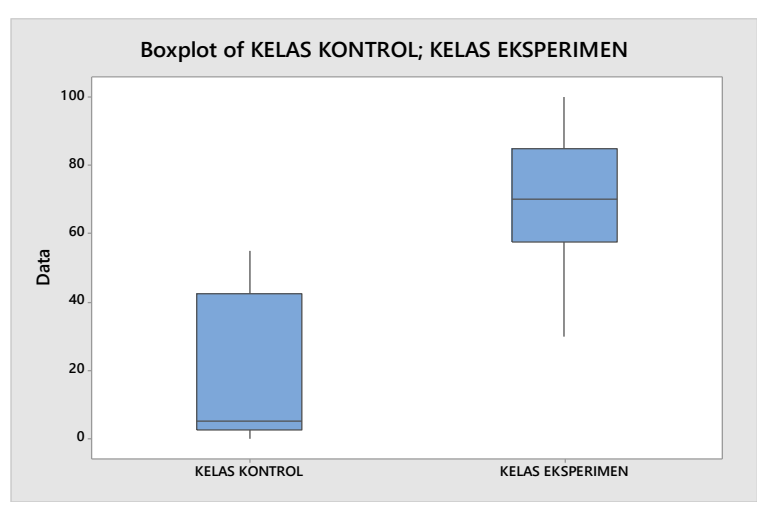

Gambar 5. Bloxplot kelas kontrol; kelas eksperimen

Hasil menunjukkan bahwa penggunaan blok aljabar dalam menemukan akar persamaan kuadrat dengan teknik kuadrat sempurna lebih efektif dibandingkan pembelajaran konvensional tanpa melibatkan blok aljabar. Dalam proses pembelajaran siswa berlatih memvisualisasikan sejumlah persamaan kuadrat dengan menggunakan blok aljabar dan mampu menerapkan teknik kuadrat sempurna sehingga siswa dapat mengarah kepada akar persamaan kuadrat yang hendak ditemukan. Dari pengamatan selama proses pembelajaran tersebut, visualisasi geometris dikatakan dapat membantu siswa "mengkonkritkan" konsep abstrak persamaan kuadrat dalam wujud geometris yang disajikan oleh blok aljabar. Sejumlah pemahaman konsep penemuan akar dapat dipahami bahkan ketika siswa tidak lagi menggunakan dan membutuhkan blok aljabar dalam penemuan akar persamaan kuadrat yang diberikan.

Meskipun masih dengan pola pikir geometris, namun proses pembelajaran dan hasil penelitian menunjukkan bahwa siswa telah mampu memaknai konstruk aljabar dengan baik. Hal ini ditunjukkan dengan mampunya siswa menemukan akar persamaan kuadrat dengan teknik kuadrat sempurna. Dengan demikian dapat dikatakan pengajaran dengan blok aljabar telah mendukung pemerolehan makna dalam pembelajaran teknik kuadrat sempurna. Hasil ini sejalan dengan pendapat Foster (2007) mengenai peran kehadiran makna dalam pengajaran terhadap perolehan pemahaman oleh siswa.

Akhirnya, hasil penelitian ini menegaskan hasil-hasil penelitian sebelumnya
(Kusumawati, 2017; Ulfa, 2017; Fachrudin, 2015; Fachrudin \& Putri, 2014) tentang peran naïve geometry sebagai proses manipulasi bentuk geometri dari persamaan kuadrat yang mampu membantu siswa dalam memahami penyelesaian persamaan kuadrat. Dengan demikian mengenalkan penggunaan blok aljabar dalam mempelajari teknik kuadrat sempurna dapat dijadikan alternatif pembelajaran penemuan akar persamaan kuadrat.

\section{Kesimpulan}

Dari hasil dan pembahasan dapat disimpulkan bahwa penggunaan blok aljabar lebih efektif dalam membantu siswa kelas IX menyelesaikan permasalahan persamaan kuadrat dengan teknik kuadrat sempurna dibandingkan dengan penggunaan metode penyelesaian yang konvensional tanpa melibatkan blok aljabar. Hasil analisis data yang dilakukan menunjukkan pencapaian dari kelas eksperimen yang jauh lebih baik dari kelas kontrol.

\section{Ucapan Terimakasih}

Ucapan terimakasih penulis sampaikan kepada Kementerian Riset, Teknologi, dan Pendidikan Tinggi yang telah mendanai penelitian dengan skema Penelitian Dosen Pemula (PDP) pada tahun 2018.

\section{Referensi}

de Lima, R. N., \& Tall, D. (2010). An example of the fragility of a procedural approach to solving equations. Citeseer.

Fachrudin, A. D. (2015). Pendekatan geometri untuk membangun konsep penyelesaian persamaan kuadrat berdasarkan perspektif sejarah. Jurnal Edukasi, 1(2).

Fachrudin, A. D., \& Putri, R. I. I. (2014). Building Students' understanding of quadratic equation concept using naïve geometry. Indonesian Mathematical Society Journal on Mathematics Education, 5(2), 192-202.

Foster, D. (2007). Making meaning in algebra: Examining students' understandings and misconceptions. Assessing Mathematical Proficiency, 53, 163-176. 
Kusumawati, I. B. (2017). Pengembangan perangkat pembelajaran dengan pendekatan sejarah naive geometry pada materi persamaan kuadrat di kelas VIII SMP. Jurnal Edukasi: Kajian Ilmu Pendidikan., 1(1), 91-100.

Lian, L. H., \& Yew, W. T. (2012). Assessing algebraic solving ability: A theoretical framework. International Education Studies, 5(6), 177-188.

Radford, L., \& Guérette, G. (2000). Second degree equations in the classroom: A Babylonian approach. Paleontological Society Papers, 6, 69-76.

Suryabrata, S. (2004). Metodologi penelitian. Jakarta: Raja Gravindo Persada.

Syafriandi. (2001). Analisis statistik inferensial dengan menggunakan minitab. Padang: UNP.

Ulfa, M. (2017). Pengembangan perangkat pembelajaran matematika dengan metode naive geometry untuk melatihkan literasi matematis siswa SMP pada materi persamaan kuadrat ( $\mathrm{PhD}$ Thesis). UIN Sunan Ampel Surabaya. 
JURNAL GANTANG. Maret 2019; IV(1): 71 - 77

p-ISSN. 2503-0671

e-ISSN. 2548-5547 